https://doi.org/10.21272/mmi.2021.1-07 JEL Classification: M15, M30, M31, O21, 032

\author{
Abeer Elsayed Fayed, \\ Ph.D., University of Tabouk, The Kingdom of Saudi Arabia \\ Academy of Specialized Studies, Egypt \\ (iD) ORCID ID, 0000-0003-4406-894X \\ e-mail: abeerfayed2@gmail.com
}

\title{
ARTIFICIAL INTELLIGENCE FOR MARKETING PLAN: THE CASE FOR E-MARKETING COMPANIES
}

\begin{abstract}
This paper summarises the arguments and counterarguments within the scientific discussion on artificial intelligence (Al) in preparing a marketing plan for e-marketing organizations. This research aims to identify the extent of the contribution of $\mathrm{Al}$ in preparing the marketing plan. The author noted that intended to know how emarketing companies could use Al techniques in situation analysis, analyze competitors' strategies, strategic goals, preparing marketing strategies, preparing an estimated marketing budget, and control a marketing plan. Systematization of the scientific background and approaches on preparing a marketing plan for e-marketing organizations indicates that many companies, especially small companies, marketing their products via the Internet, cannot develop a successful marketing plan. In turn, it could be solved through the use of Al techniques. The study was conducted on a group of companies that market their products via the Internet in the Kingdom of Saudi Arabia. To gain the research goal, this study was carried out in the following logical sequence: 1) developing the stratified sample by collecting statistical information for 141 company in a variety of fields; 2) analyzing the data using SPSS; 3) predicting how Al could be used in preparing the marketing plan; 4) identifying the arrangement of the steps for preparing the marketing plan in terms of the ability of Al techniques. The methodological tools of the study were methods of the multiple regression analysis and the Friedman test. The study empirically confirms and theoretically proves that $\mathrm{Al}$ contributes significantly in developing marketing plans through its great contribution to environmental analysis and analysis of competitors' strategies and setting marketing goals. Besides, Al contributes to preparing the budget and appreciating the marketing plan, to its evaluation and control. The author mentioned that Al provides understanding and selecting target markets and sectors, targeting customers, and preparing appropriate marketing mix strategies for each market sector. Therefore, the study provides recommendations to online organizations to use $A$ l in preparing their marketing plan because of its great ability to contribute to this.
\end{abstract}

Keywords: artificial intelligence, e-marketing, environmental analysis, marketing strategies, marketing plan, strategic goals.

Introduction. Many fields are increasingly dependent on artificial intelligence (Al) with accelerated steps, proving its effectiveness. Soon, it will become a necessity to be used. One of these fields that Al has begun to enter into is e-marketing. It is expected to have a strong contribution to improving the mechanisms of e-marketing to become more effective and more profitable. There is an assumption that next year (2021), companies will spend 57 billion dollars on Al platforms (Harrison, 2019). Al is also expected to contribute about 15.7 trillion dollars to the global economy by 2030 and 135.2 billion dollars to the Saudi GDP, equivalent to $12.4 \%$ by 2030 (Al Jazira, 2019).

Artificial intelligence offers modern technologies that mimic the human element and may even surpass it. They could contribute greatly to making radical changes in e-marketing (Harris, 2019). Large medium and small enterprises could use Al technologies to increase their profits significantly.

There is no doubt that the basis for successful marketing is preparing a successful marketing plan. It is noted that many e-marketing companies cannot prepare a successful marketing plan that accompanies their online business (Long et al., 2020). That is despite the presence of technologies that

Cite as: Elsayed Fayed, A. (2021). Artificial Intelligence for Marketing Plan: the Case for E-marketing Companies. Marketing and Management of Innovations, 1, 81-95. http://doi.org/10.21272/mmi.2021.1-07 
could contribute to preparing the marketing plan for these companies successfully to make them more efficient.

Nowadays, Al is considered to be one of the most important of these technologies. It could contribute to preparing the marketing plan more effectively that improves the customer experience (Paschen et al., 2019). It also facilitates the work of marketers. Besides, Al could carry out most of preparing the marketing plan more masterly than humans (Grewal et al., 2020). In the recent past, emarketing was just a complementary marketing method that companies might or might not rely on. Now it has become a necessity for life, especially after the spread of the coronavirus pandemic. Likewise, Al is now a choice for companies to rely on or not. However, soon, it will become necessary to improve business and increase profits of organizations that use e-marketing. Accordingly, companies must try to rely on $\mathrm{Al}$ and find the required mechanisms to improve e-marketing tasks.

Perhaps the most important marketing task, in general, is to develop a successful and reliable marketing plan for the success of the entire marketing process. Organizations must find all means through which they could improve the work of the marketing plan.

Many e-marketing companies suffer from their inability to prepare a successful marketing plan that is compatible with marketing their products electronically. That inevitably leads to its failure in marketing and being excluded from the competition. These companies should search for the mechanisms necessary to prepare a successful marketing plan commensurate with their work online.

$\mathrm{Al}$ is a new and critical mechanism for developing and improving companies work in all its aspects. The most important of that is developing a marketing plan commensurate with e-marketing (Rai, 2020). The companies should benefit from this great technical development in improving and developing the marketing plan preparation (Kumar and Gupta, 2016). It is noted that most e-marketing companies still have not relied on it in general in developing their business online and in particular in preparing the marketing plan. They rely on it in very limited matters that could be limited to instant chat. These companies still have not known that through the available Al technologies (which some may already be used), they could prepare a successful marketing plan if they exploit them.

Where Al allows identifying opportunities, threats, strengths and weaknesses of the organization and the strategies of competitors, it could determine the organization's objectives, its various strategies, the budget and follow-up and follow up the implementation of the marketing plan of the organization.

For this, the main question of the research problem could be proposed as follows: «How feasible is the use of Al technologies as an approach to prepare a successful marketing plan for e-marketing companies?»

This main question of the present research is divided into the following sub-questions:

Could Al be used in situation analysis (environmental analysis) in e-marketing companies?

Could Al be used to analyze competitors' strategies in e-marketing companies?

Could Al be used to define strategic goals in e-marketing companies?

Could Al be used in preparing marketing strategies in e-marketing companies?

Could Al be used in preparing an estimated budget in e-marketing companies?

Could Al be used in evaluating and controlling a marketing plan in e-marketing companies?

Therefore, this article explores how e-marketing companies could use Al techniques: 1) in situation analysis (environmental analysis); 2) to analyze competitors' strategies; 3) to define strategic goals; 4) in preparing marketing strategies; 5) in preparing an estimated marketing budget; 6 ) to evaluate and control a marketing plan.

Literature Review. Given the research topic's novelty, rare studies dealt with certain aspects of the current research topic. The studies have found the importance of $\mathrm{Al}$ in having strong interaction with customers (Boyd and Holton, 2018). Through instant chatbots, Al interacts strongly with customers. It 
allows recognizing customers' feelings (Jonnalagadda, 2019) and analyzing the consumer's emotional state by chatting with robots and communication media (Harrison, 2019).

Al could analyze the organization's opportunities, external threats, strengths, and weaknesses (Sentence, 2019; Goldberg, 2018; Nasser, 2018). That is possible by collecting data, whether from inside or outside the organization, and then analyzing it to identify the organization's weaknesses, strengths, opportunities, and threats (Goldberg, 2018). In turn, if the Al could identify the organization's opportunities as soon as they are available, it allows progressing over competitors (Sentence,2019).

Al could determine changes in competitors' strategies (Tjepkema, 2019). For example, it could determine changes in the prices of their products (Davis, 2018), carefully analyze these strategies (Pedersen, et al., 2018), and identify the level of competitors' websites (Bakhsh, 2019).

Al could help an organization set its own goals (Paschen et al., 2019), which requires internal data for marketing such as sales support data, advertising sites and media, and external data such as census data, demographics, and consumer confidence (Chandan, 2019; Long et al., 2020). Al allows defining the factors affecting an organization (Kietzmann et al., 2018), including the market share and product demand (Jarrahi, 2018; Vijayaraghavan, 2019). It could also do market research to learn about consumer characteristics and satisfaction, customer data, sales, and market share (Ferrell and Ferrell, 2020; E-marketing, 2019). This data assure a better set of the organization's long- and short-term marketing goals (Herald, 2018).

Al contributes to understanding and targeting customer, as well as determining their desires (Davenport and Kirby, 2016), preferred platforms (Boyd and Holton, 2018), identifying their characteristics, desires and behaviour (Santanen, 2019), and their inquiries answered through instant chat (Barro and Davenport, 2019). Al could reach the target audience more specifically (Al Lababidi, 2018). Besides, it could discover customer behaviour, feelings, and the places in which they are (Inversini and Masiero, 2014) and identify the extent of their satisfaction with products (Duan et al., 2019). Al could deal with clients personally and satisfy each client's desires individually. (Gordini and Veglio, 2017).

Al could recognize the customers' preferences in products' types and designs (Longoni et al., 2019). It could also estimate the demand for products (Davenport and Ronanki, 2018) and identify product alternatives (Dedehayir and Streinert, 2016). Al could classify products very efficiently (Long et al., 2020). It could also transform customers' desires for products into reality people couldn't do (Davenport et al., 2020). Because it is used in testing a product before it is offered on a website through the sites designated for that, the surprise from not accepting the product is almost excluded (Castelo, 2019). Al identifies the customers' desires that competitors have not met to improve them (Jabbar et al., 2020).

Pedersen et al. (2018) noted Al could create an attractive website in simple steps. It contributes significantly to designing websites according to customers' information, such as images, texts and phrases that urge them to purchase (Mende et al., 2019).

Singh et al. (2019) found that Al could define pricing strategies to increase sales. It helps the organization reach the right price for the products using the flexible pricing strategy (Shankar, 2018). In the study (Hoffman and Novak, 2018), the author concluded that Al could also detect pricing errors and fraud. Liu (2020) mentioned Al could adjust quotations according to customers' desires and compare competitors' prices and the organization's prices.

Through Al, distribution channels suitable for customers are identified (Kaplan and Haenlein, 2019), and optimal distribution and storage decisions are made (Syam and Sharma, 2018). It is also used in warehouse management to detect weaknesses in a supply chain and forecasts potential sales (Tjepkema, 2019). Paschen et al. (2019) indicated that Al could identify the organization's product movement data and enable audio and visual searches 
In the study (Yilun and Michal, 2018), the authors found that Al contributes to improving the means of product promotion. It offers programmed ads and videos targeting customers according to their personality (Davenport et al., 2020). It could also identify suitable for customers promotion and improve it for future campaigns according to the achieved results (Hoffman and Novak, 2018). Besides, suitable for customers offers are provided (Shankar, 2018).

Castelo (2019) found that Al helps an organization identify a budget suitable for it through the set prices. It encourages an organization to evaluate the results by setting criteria for a plan's success and monitoring work progress during plan implementation (Lashinsky, 2019). The paper (Sentence, 2019) noted that $\mathrm{Al}$ identifies the problems that face a marketing plan's performance. Al contributes to making search results on the first page of search results more relevant. These have also become more valuable and useful than before by optimizing search engines (SEO) (Zhang and Cabage, 2017).

The scientific developments indicate limited studies on Al technologies' potential contributing to emarketing companies' prosperity, especially in preparing the marketing plan. Besides, none of the scientific studies touched on the Al techniques contribution in preparing the marketing plan for emarketing companies. That is a clear deficiency in this scientific development, which would be addressed in the current study. Based on theoretical scientific background and previous studies, Adami (2015) has reached the following hypotheses: advances in Al technologies have provided a great opportunity for e-marketing organizations to do an environmental analysis more easily, cost-efficiently and effectively. Al could provide all necessary data for that (Boyd and Holton, 2018). Therefore, situation analysis (environmental analysis) of an organization could be reached (Andre et al., 2018). Al provides the organization's internal data collection to identify the organization's strengths and weaknesses (Syam and Sharma, 2018) and external data collection to identify the organization's possible opportunities and threats (Wang et al., 2020). Thus, Al could identify opportunities and threats as they arise, exploit opportunities before competitors, and confront the organization's threats (Ransbotham et al., 2019).

Accordingly, the first hypothesis ( $\mathrm{H} 1)$ could be formulated as follows: there would be a significant correlation between using Al techniques and situation analysis (environmental analysis) as one of the steps in preparing a marketing plan.

Artificial intelligence also enables organizations to identify competitors' strategies, especially pricing strategies and biddings offered (Davenport and Kirby, 2016). It is possible to identify the product range (Fleming, 2019), promotion methods (Hoffman and Novak, 2018), and distribution channels (Hoffman and Novak, 2018). These could identify marketing strategies used by competitors (Huang and Rust, 2018). Al could identify the organization's goals, strategies, and long-term and short-term plans (Dwivedi et al., 2019) and the short or long-term goals of clients (Roetzer, 2019). It could also learn about the daily movements of customers such as quotations and identify any changes that occur in their product assortment (Batra and Keller, 2016), and identify changes that occur in their goals, plans, strategies and actions towards their marketing mix as soon as they occur (Shankar, 2018).

Accordingly, the second hypothesis ( $\mathrm{H} 2)$ could be formulated as follows: there would be a significant correlation between using Al techniques and analyzing competitors' strategies as one of the steps in preparing a marketing plan.

By identifying situation analysis and competitors' strategy analysis, Al could define long- and shortterm goals for e-marketing companies (Castelo, 2019). Al identifies all data necessary to set goals for these companies (Davenport et al., 2020). By identifying the opportunities and threats that may face the organization and identifying the strengths and weaknesses of the organization, Al could reach the organization's goals (Soni et al., 2019). By learning about customers' preferences and desires, Al could reach the marketing goals of the organization (Shahid and Li, 2019). 
Accordingly, the third hypothesis $(\mathrm{H} 3)$ could be formulated as follows: there would be a significant correlation between using Al techniques and setting strategic marketing goals as one step in preparing a marketing plan.

Al makes it possible to contribute to various marketing strategies, which are the most important steps in preparing the marketing plan (Overgoor et al., 2019). It could also choose the market sectors that suit the products offered by the organization and then target customers better (Ajanthan, 2017) and reach the appropriate marketing mix for the organized products.

Accordingly, the fourth hypothesis ( $\mathrm{H} 4$ ) could be formulated as follows: there would be a significant correlation between using $\mathrm{Al}$ techniques and preparing marketing strategies as one step in preparing a marketing plan.

Artificial intelligence is used in preparing marketing strategies, as it could obtain information necessary to understand the target markets and market sectors (Grewal et al., 2020). It is used to obtain information on market share and the quantity of demand (Rai, 2020). It could divide markets into target segments according to their characteristics (Shankar, 2018). It is also possible, through artificial intelligence, to identify access to different segments of customers and then provide appropriate products and prepare appropriate marketing strategies for each segment (Ozcelik and Varmali, 2019).

Accordingly, the fourth hypothesis's first sub-hypothesis could be formulated as follows: there would be a significant correlation between using Al techniques and understanding and choosing target markets and sectors as one step in preparing a marketing plan.

Al could understand markets and market sectors. Besides, it could understand customers and target them distinctly (Singh et al., 2019; Rajkomar et al., 2019). Al is used to track customers online to learn about their purchasing behaviour and characteristics (Goldberg, 2018) and analyze their feelings while chatting (Tjepkema, 2019). It is also possible to access the appropriate content for customers and present it individually to each client according to his desires and characteristics (Morgan et al., 2019).

Accordingly, the fourth hypothesis's second sub-hypothesis could be formulated as follows: there would be a significant correlation between using $\mathrm{Al}$ techniques and understanding and targeting customers as one step in preparing a marketing plan.

Al could also prepare a marketing mix strategy for each of the identified market sectors (Hammett, 2018). The products could be continually designed and developed by following consumer preferences online through Al (Harris, 2019). Indeed, Al could define product components according to customers' needs and desires (Jarrahi, 2018). It could also set a price strategy suitable for each customer, known as flexible pricing (Talbot, 2019). Besides, Al could determine appropriate distribution channels (Jarvinen and Taiminen, 2016) and track inventory movement, sales, supply movements, and sales analysis (Lessmann et al., 2019). And identify promotional methods and means (Vincent and Gartenberg, 2019) and the content of the promotional message to customers (Walk-Morris, 2020). Al provides presenting the promotional message in the form that suits customers, such as drawings, videos, images and texts (Abid et al., 2019). It could also learn about the purchasing power of customers and provide products that suit them.

Moreover, Al compares the organization's products' prices with competitors' products' prices (Simon, 2019). Using Al, the organization identifies the problems in terms of supply and supply movements, periods of demand congestion, and periods of depressed demand (Kietzmann et al., 2018). Besides, the organization could provide the promotional message according to customers' characteristics, identified through collecting and analyzing customer information (Khodabandehlou and Rahman, 2017). It could also improve promotional messages and send them again according to the changes that may occur to the customer (Shen, 2014). Using Al, e-mail could be used to promote the product based on identifying the customer's characteristics previously identified and then sending an e-mail to each customer according to his characteristics and desires in the products presented (Raunaque et al., 2016). 
Accordingly, the fourth hypothesis's third sub-hypothesis could be formulated as follows: there would be a significant correlation between using $\mathrm{Al}$ techniques and preparing marketing mix strategies suitable for each market sector as one step in preparing a marketing plan.

Using marketing strategies, Al could identify necessary expenditures and determine a marketing plan budget (Kietzmann et al., 2018; Sams, 2018). It could be adjusted according to any changes that may occur to the organization's strategies, requirements and market changes (Sanchez, 2018).

Accordingly, the fifth hypothesis (H5) could be formulated as follows: there would be a significant correlation between using Al techniques and preparing an estimated budget of a marketing plan as one step in preparing a marketing plan.

Having set plans, each organization should follow up on and monitor its implementation correctly (Quast, 2019). Al could follow up on implementing a market plan (Singh et al., 2017) and set regulatory standards necessary according to the developed plan (Arthur, 2019). Necessary control is then maintained (Columbus, 2019), and, if necessary, corrective actions are taken (Lashinsky, 2019).

Thus, the sixth hypothesis (H6) could be formulated as follows: there would be a significant correlation between using Al techniques and evaluation and control over a marketing plan as one step in preparing a marketing plan.

Methodology and research methods. The study has relied on the descriptive-analytical method. The study reviewed the scientific background on this topic and then completed the gap points. Then, the hypotheses were determined. The raw data were collected to prove or reject the hypotheses. Therefore, recommendations were made based on the obtained findings. The collection of study data has been based on a questionnaire form. It was distributed electronically to the sample elements. The questionnaire was based on the questions according to the five-point Likert scale. The respondents' views have been identified about to what extent the techniques provided by Al could be relied on in preparing a successful marketing plan.

The research objects are the Saudi e-marketing companies that display their products online. The study provides a stratified random sampling method. The sample was taken from each business according to the ratio of each to the total economic businesses according to the statistics of the Saudi General Authority for Statistics. The sampling unit consisted of those responsible for the project, as the officials are the persons responsible or not for using Al techniques. Accordingly, Table 1 shows the sample size.

Table 1. The sample size of the study

\begin{tabular}{lclc}
\hline \multicolumn{1}{c}{ Type of Business } & Sample Size & \multicolumn{1}{c}{ Type of Business } & Sample Size \\
\hline Garments & 12 & Games and entertainment & 8 \\
Shoes and bags & 10 & Furniture & 9 \\
Make-up and perfumes & 9 & Electrical appliances & 5 \\
Accessories and watches & 8 & Decors & 7 \\
Books & 5 & Accommodation and food & 11 \\
Food and beverage products & 19 & Tourism & 8 \\
Educational courses & 9 & Information and communication products & 9 \\
Electronic devices & 5 & Stationeries & 7 \\
Total sample size & 141 & & \\
\hline
\end{tabular}

Sources: developed by the author.

Table 1 indicates that the number of elements reached 141. There are 134 elements that answered the form. The response rate was $95 \%$. It stands to mention that it is a very high percentage whose results could be generalized. The study relied on some analyses of descriptive statistics and statistical methods included in the SPSS. The multiple regression analysis was relied on, and the Friedman test was also used. In this study, the focus was on examining how Al techniques are used in preparing a 
marketing plan only without the rest of the marketing operations. The application was also limited to some e-marketing companies of the Kingdom of Saudi Arabia. Figure 1 illustrates the model for data analysis.

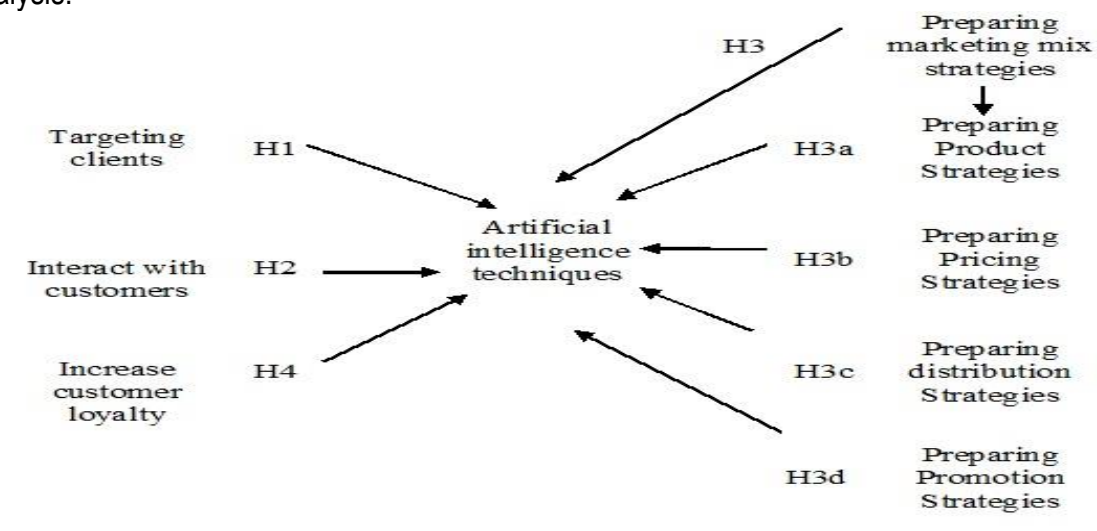

Sources: developed by the author.

Figure 1. Study model

It means the precision of research in measuring the purpose for which it was designed. To achieve this purpose, the questionnaire form was presented to several professors of marketing. They explained the adjustments. It means that reliable and valid results could be obtained by scientific research. To ensure the reliability of the measuring instrument, Cronbach's alpha analysis was used. It means accepting the question's statements that exceed $60 \%$. Table 2 provides the results.

Table 2. Cronbach's alpha analysis to test the reliability of the measuring instrument

\begin{tabular}{lcc}
\hline \multicolumn{1}{c}{ Focus of question } & \# of paragraphs & $\begin{array}{c}\text { Cronbach's } \\
\text { alpha }\end{array}$ \\
\hline The extent to which $\mathrm{Al}$ is used in environmental analysis & 8 & $88 \%$ \\
The extent to which Al is used in analyzing competitors' strategies & 5 & $86 \%$ \\
The extent to which Al is used in defining strategic marketing objectives & 6 & $82 \%$ \\
The extent to which Al is used in understanding and choosing market sectors & 7 & $87 \%$ \\
The extent to which Al is used in targeting customers & 10 & $91 \%$ \\
The extent to which Al is used in preparing marketing mix strategies for each & 12 & $92 \%$ \\
market segment & 5 & $85 \%$ \\
The extent to which Al is used in preparing an estimated marketing budget & 7 & $84 \%$ \\
The extent to which Al is used in evaluating and controlling the implementation & 10 & $90 \%$ \\
of a marketing plan & & \\
The use of Al in e-marketing companies
\end{tabular}

Sources: developed by the author.

Results. The study results indicate that $78 \%$ of the sample does not know how to use existed $\mathrm{Al}$ techniques in preparing the marketing plan. In turn, $15 \%$ knows how useful it is. However, they do not know the mechanism that could be used for that. $7 \%$ knows how to benefit from it and has already used many $\mathrm{Al}$ techniques in preparing their marketing plan. 
The results also show that $5 \%$ of the sample uses Al techniques in preparing some steps of the marketing plan. In turn, 95\% does not do the same. Regarding the study hypotheses, the multiregression analysis was used to predict how Al allows preparing the marketing plan (Table 3).

Table 3. Results of multiple regression analysis

\begin{tabular}{cccccccc}
\hline Hypothesis & $\mathrm{R}$ & $\mathrm{R} 2$ & Beta & $\mathrm{F}$ & $\mathrm{T}$ \\
\hline H1 & 0.836 & 0.811 & 1.82 & 120.238 & 0.001 & 68.59 & 0.003 \\
H2 & 0.798 & 0.774 & 1.75 & 178.271 & 0.000 & 83.24 & 0.001 \\
H3 & 0.912 & 0.903 & 2.01 & 156.12 & 0.000 & 75.56 & 0.001 \\
H4a & 0.932 & 0.910 & 1.96 & 164.81 & 0.000 & 92.37 & 0.000 \\
H4b & 0.965 & 0.941 & 1.52 & 135.96 & 0.000 & 82.79 & 0.000 \\
H4c & 0.954 & 0.933 & 1.48 & 126.87 & 0.000 & 76.97 & 0.000 \\
H5 & 0.764 & 0.719 & 2.59 & 146.89 & 0.002 & 68.91 & 0.006 \\
H6 & 0.829 & 0.784 & 2.26 & 135.19 & 0.003 & 76.32 & 0.003 \\
\hline
\end{tabular}

Sources: developed by the author.

Table 3 and the first hypothesis analysis results $\mathrm{R}$ is approximately $84 \%$. The results also show that e-marketing companies could rely on Al techniques to conduct environmental analysis (R2 is $81 \%$ ). Tvalue demonstrates the significance of the correlation at $5 \%$ significance level. Therefore, the alternative hypothesis could be accepted, rejecting the null hypothesis.

The table data and testing the second hypothesis indicate a correlation between using Al techniques and the organization's ability to conduct competitor strategies analysis as the second step in preparing the marketing plan (R-value is $80 \%$ ). Regarding the extent to which Al techniques could be relied on in analyzing competitors' strategies ( $R 2$ is $77 \%$ ). The model is significant by T-value at $5 \%$ significance level. Thus, the alternative hypothesis could be accepted, rejecting the null hypothesis.

By analyzing the third hypothesis's results, the results show a correlation between using $\mathrm{Al}$ techniques and the organization's ability to define its strategic marketing goals as the third step in preparing the marketing plan ( $\mathrm{R}$ is $91 \%$ ). E-marketing companies could rely on Al techniques to define their strategic marketing goals, as R2 is $90 \%$. The model is significant by T-value at $5 \%$ significance level. Therefore, the alternative hypothesis could be accepted, rejecting the null hypothesis.

The fourth hypothesis was divided into three sub-hypotheses. The results of examining H4a show a very strong correlation between usingAl techniques and e-marketing companies' ability to understand and choose the targeted market sectors as the first stage of the fourth step in preparing the marketing plan ( $R$ is $93 \%$ ). The results also indicate that $\mathrm{Al}$ techniques could be relied on to understand and choose the targeted market sectors ( $R 2$ is $91 \%$ ). The model is significant by T-value at $5 \%$ significance level. Therefore, the alternative hypothesis could be accepted, rejecting the null hypothesis.

The same applies to $\mathrm{H} 4 \mathrm{~b}$. The results show a very strong correlation between using Al techniques and e-marketing companies' ability to understand and target customers, as the second stage of the fourth step in preparing the marketing plan ( $R$ is $96 \%$ ). Regarding the extent to which these companies rely on Al techniques to understand and target customers, R2 is $94 \%$. T-value at $5 \%$ significance level demonstrates the significance of the model. Therefore, the alternative hypothesis could be accepted, rejecting the null hypothesis.

The results of $\mathrm{H} 4 \mathrm{C}$ also show that e-marketing companies could rely on Al techniques in preparing marketing mix strategies as the third stage of the fourth step in preparing the marketing plan (R2 is $93 \%$ ). The correlation is also very strong between Al techniques and marketing mix strategies ( $R$ is $95 \%$ ). T-value demonstrates the significance of the model at $5 \%$ significance level. Therefore, the alternative hypothesis could be accepted, rejecting the null hypothesis. 
On the fifth hypothesis, the results clarify the strong correlation between using $\mathrm{Al}$ techniques and preparing the marketing plan's estimated budget as the fifth step in preparing the marketing plan ( $R$ is $76 \%$ ). These techniques could also be relied on to prepare the budget by R2 equal $71 \%$. T-value demonstrates the significance of the model at $5 \%$ significance level. Therefore, the alternative hypothesis could be accepted, rejecting the null hypothesis.

The same applies to the sixth hypothesis. Table 3 demonstrate that the correlation is strong between e-marketing companies using $\mathrm{Al}$ techniques, evaluation and control of the marketing plan as the sixth step in preparing the marketing plan ( $\mathrm{R}$ is $83 \%$ ). These companies could rely on $\mathrm{Al}$ techniques to evaluate and control the marketing plan (R2 is 78\%). T-value demonstrates the significance of the model at $5 \%$ significance level. Therefore, the alternative hypothesis could be accepted, rejecting the null hypothesis.

To identify the arrangement of the steps of preparing the marketing plan regarding Al techniques, the Friedman test was also used. Table 4 demonstrate its results.

Table 4. Results of Friedman test

\begin{tabular}{cccc}
\hline Hypothesis & Rank mean & $\chi 2$ & Significance \\
\hline H4b & 8.64 & & \\
H4a & 8.21 & & \\
H4c & 7.80 & 694.561 & 0.000 \\
H1 & 7.14 & & \\
H3 & 6.29 & \\
H2 & 5.53 & \\
H6 & 3.94 & \\
H5 & 3.26 & & \\
\hline
\end{tabular}

Sources: developed by the author.

The results of Table 4 state that the level of significance is less than $5 \%$. That indicates a significant variance in the respondents' opinions, which indicates that the techniques of Al do not contribute equally to achieving all the steps of preparing the marketing plan. Instead, the respondents believe that there is variance in that. Al could contribute to preparing the steps of the marketing plan in varying degrees for each step. It could contribute to a step more than another one. The results show that $\mathrm{H} 4 \mathrm{a}$ achieves the highest rank mean (8.64). Thus, understanding and targeting customers are the step Al could contribute to in preparing the marketing plan. It is followed by the step of understanding and choosing markets and market sectors. Then comes the step of preparing the marketing mix strategies. The environmental analysis step follows, then defining strategic marketing goals. That is followed by the step of analyzing competitors' strategies. Then comes the step of evaluation and control of the marketing plan. The results also show that the fifth hypothesis (preparing the estimated budget) is the last step that Al could contribute to the preparation, as it achieves the lowest rank mean (3.26).

Based on the previous analysis, it is clear that Al continues to grow in all areas. It has become an important necessity in many areas and is expected to be so for e-marketing. The present study has clarified several important points, the most important of which are:

- Al could analyze opportunities, external threats, strengths and weaknesses of an organization. It could collect internal and external data, analyze them accurately and determine what they offer of opportunities or external threats to the organization and the strength or weakness they provide within the organization. Al could thus identify marketing opportunities as they happen. Then, Al makes the proper decision on how to take advantage of this opportunity. Likewise, any threat that the organization may face will be identified by Al. It takes the proper decision to overcome and deal with it as appropriate. As with opportunities and threats, Al could also identify strengths and weaknesses within an organization. 
That is consistent with the studies (Fleming, 2019; Castelo,2019), which clarified the possibility to conduct the environmental analysis. They identify opportunities, threats, strengths and weaknesses using Al techniques.

- Al is used to accurately identify and analyze all competitors' strategies. Then, their future moves are identified; the actions necessary are taken to outdo them, to be prepared for any actions that competitors may take. Al could identify the marketing mix strategies of competitors such as the pricing strategies used, the quotations they offer, the means of promotion they follow, their distribution channels, the range of the products provided through their websites, and any changes in their strategies. The literature (Paschen et al., 2019) has shown the same as the field study found out. The different strategies of competitors could be identified to be then prepared for and face them with the company's appropriate marketing strategy.

- Al helps the organization better define long- and short-term marketing goals for the organization. By identifying the organization's environmental analysis, identifying opportunities, threats, strengths and weaknesses, and identifying competitors' different strategies, the organization could properly define its goals. The scientific background (Tjepkema, 2019) demonstrates the ability to define companies' goals by Al. Identifying and analyzing the competitors' strategies and the company's environmental analysis was conducted by Al.

- Al could understand markets properly. It could identify the market sectors accurately by targeting customers and identifying their characteristics, data, demographics and purchasing capabilities. It could also identify the quantity of expected demand and revenue, each target market sector's specific needs, the preferable types of company and competitors products. Consequently, it could divide customers into different segments and then target each segment or sector according to the marketing mix elements. Sentence (2019) found that the Al potentials provided companies with identifying markets and dividing them into distinct market sectors.

- Al techniques allow recognizing the online customers' nature, their actions and behaviour in the online environment. It contributes to identifying customers' preferences, tastes and personalities, identifying their feelings and ways of responding to the marketing mix and the places they are online, how satisfied they are with the products and their vision of these products by analyzing social media. With this, organizations could focus on content that attracts and persuades customers to buy. It also makes the necessary adjustments according to customers' needs, desires, characteristics, and online behaviour. This process is similar to the human. They could also identify consumer satisfaction with products and consumer purchasing patterns. Al could personalize customers. It identifies customers in detail, and directs the personalized marketing mix, separates and distinguishes customers from each other. Therefore, each customer feels personalization. It fulfils their desires personally in detail. The studies (Long et al., 2020; Rajkomar et al., 2019) found out that the Al techniques could track customer behaviour and identify their characteristics, needs and preferences.

- Al also classifies customers into segments. Thus, it allows targeting customers with the right ads and adjusting suitable products. Their inquiries are also answered through instant chat. Al could identify gaps in past customer targeting operations and then improve them in the future to reach more specifically the target audience. By identifying consumer online behaviour and linking it with big data, $\mathrm{Al}$ could offer them products that match their preferences and personality. In addition, it could design customer loyalty programs and customer interaction programs managing customer relationships electronically. The studies (Ferrell and Ferrell, 2020; Mende et al., 2019) indicated that after identifying customer characteristics online, ads relevant to them could be directed in the ways they prefer. Thus, it allows attracting them to buy and interact with customers.

- Al could recognize customers' preferences, types of products, designs and components. It specifies the technical requirements and the types of materials needed for the product, coding them and 
undertaking rapid design to suit customers' needs. It could also estimate the demand for products. Al could identify the alternatives available for products. Besides, it could identify gaps in the market to develop new and more specialized products. By artificial intelligence, the range of products could be determined. Inventory, price, sales and supply movements of the website and competing ones are tracked. The sales and returns of sold products are analyzed. Hence, the best-selling products are identified, expanding their production and displaying them through the website. The same applies to the products that are not popular, excluding or reducing them later. Al could classify products very efficiently, tag them, and then correctly identify products. It stands to mention that Al is also used to educate customers about the product and test it virtually online as it happens in reality. In the study (Davenport et al., 2020), the authors identified and tracked customer characteristics online. Therefore, it indicated that it is possible to provide products that suit their needs and desires.

- Al could transform customers' desires into products a human may not be able to do so.

- Through Al, the products are tried before they would be introduced to the customers. Thus, the producers could ensure whether the customers accept the product or not.

- By Al, the most attractive for customers organization's website could be created and under a few simple steps. That is by identifying the characteristics of customers and their acceptance of graphics, texts and content online. Grewal et al. (2020) showed that it is necessary to take care of the site to attract customers, which Al could do in simple steps.

- Al could define pricing strategies, as Al uses a dynamic pricing strategy. It could also adjust biddings continuously based on the number of website visitors. Besides, the prices of marketing campaigns could be adjusted by analyzing data, making proposals for developing the campaign and implementing the proposals related to this development. It could also predict what a customer might be willing to pay through the data it extracts from their behaviour online. Thus, each customer is given reasonable prices and offers. It is also used to compare the prices of the company's products with those of competitors and then determine the suitability of prices in the market and whether they are higher or lower than competitors' are. The studies (Rai, 2020; Andre et al., 2018) showed that it is possible to determine the appropriate prices for each customer due to the possibility of determining their characteristics individually and identifying the prices and offers that are appropriate and commensurate with their capabilities.

- By $\mathrm{Al}$, suitable for an organization logistics and distribution strategies could be identified. Warehouses could be better managed and planned. It could also define organization product movement data and enable voice and video search. Besides, it is used to identify problems that products could face online due to changing seasons or delays caused by any emergencies, such as in the spread of coronavirus pandemic. It resulted in an excess demand that many sites could not meet, and only major international companies already used Al could meet it. Grewal et al. (2020) noted that Al could identify suitable distribution methods for customers.

- Al improves the methods of promotion used. It identifies customers' characteristics and thus offers them the appropriate means of advertising in the right place and time to buy products from customers. Besides, Al could create advertisements according to customers' personality through the website and present offers suitable for them. It focuses on the content of the message that it wishes to deliver to customers. It could also better redirect ads to customers according to their characteristics and needs. Furthermore, Al could design banners for the marketing campaign through the images, texts, content, and videos available on the website. In turn, it allows choosing the best designs after testing them in the sites designated for that, all this without any human intervention. It could also identify the best channels through which the advertisement is presented according to the type of campaign offered and even provides the ad to a specific customer to deliver a specific message to him. It could also promote through e-mail sending messages to customers as if the human element was the one who did so. 
Besides, it contributes significantly to SEO. Pedersen, et al. (2018) clarifies that after determining online customers' characteristics, the promotional methods suiting them could be used to attract customers for buying.

- In addition, the chatbots provided by Al have a great role in interacting with customers in addition to identifying their preferences and feelings through their tone of voice and their responses through chatting. Castelo (2019) found that chatbots play a great and important role in interacting with customers and identifying their characteristics.

- Al contributes to setting the organization's budget based on revenue expectations and forecasted profit. In turn, the same applies to the online identification of product prices. Al estimates the marketing costs for the promotion, distribution or design and development of products. It could also automatically control the spending process and budget rationalization. Under the identification of the marketing mix costs, Hammett (2018) clarified that companies could determine the estimated marketing budget in accordance with an estimate of the company's costs.

- Al evaluates results and controls the plan implementation. It also contributes to identifying the problems facing the marketing plan's implementation. Besides, Al allows forecasting the causes of recurrent problems. Te organizations could define and control performance measures through Al. The necessary corrective actions are determined if necessary and predict the impact of these actions. Then, the corrective actions are taken to prove the bad results. It could also identify spam e-mails and electronic frauds. Thus, Al could prevent potential danger. Columbus (2019) agrees with the present study in terms of the possibility of evaluating and controlling results and taking corrective actions if necessary.

Conclusion. This study deal with $\mathrm{Al}$ as an entry point for preparing a marketing plan for e-marketing organizations. The paper identifies the potential contribution of $\mathrm{Al}$ in developing marketing plans. The findings showed that Al significantly contributed to developing marketing plans by contributing to environmental analysis and analysis of competitors' strategies. Besides, Al enhances setting marketing goals. The author noted the Al contribution to preparing the budget, the appreciation of the marketing plan, and its evaluation and control. Besides, Al contribution to preparing marketing strategies was highlighted due to its contributions to understanding and selecting target markets and sectors, understanding and targeting customers, and preparing appropriate marketing mix strategies for each market sector.

The obtained results showed that Al leads to a major technological shift in preparing marketing plans, especially for companies operating in the online environment. Therefore, organizations should rely on $\mathrm{Al}$ in developing marketing plans to benefit from technological advances and get many advantages and contributions of $\mathrm{Al}$ in this field.

\section{References}

Abid, A., Harrigan, P., \& Roy, S. K. (2019). Online relationship marketing through content creation and curation. Marketing Intelligence and Planning, 18(2), 105-116. [Google Scholar] [CrossRef]

Adami, C. (2015). Artificial intelligence: Robots with instincts. Nature, 52(7), 426-427. [CrossRef

Ajanthan, D. (2017). The impact of a social media marketing on customer based brand equity-a special reference to travel \& tourism industry in sri lanka. TRANS Asian Journal of Marketing \& Management Research (TAJMMR), 6(11), 36-46. [Google Scholar]

Al Jazira. (2019). Artificial Intelligence. Retrieved from [Link]

Al Lababidi, W. (2018). Al Increases Website Sales by 50\%. Dubai Media Incorporated. Retrieved from [CrossRef

André, Q., Carmon, Z., Wertenbroch, K., Crum, A., Frank, D., Goldstein, W., ... \& Yang, H. (2018). Consumer choice and autonomy in the age of Al and big data. Customer Needs and Solutions, 5(1), 28-37. [Google Scholar] [CrossRef]

Arthur, R. (2019). AB InBev trials drones and Al in-store to improve inventory visibility.

Bakhsh, S. (2019). The Role of Al in Marketing. Retrieved from [Link] 


\section{A., Elsayed Fayed. Artificial Intelligence for Marketing Plan: the Case for E-marketing Companies}

Barro, S., \& Davenport, T. H. (2019). People and machines: Partners in innovation. MIT Sloan Management Review, 60(4), 22-28. [Google Scholar]

Batra, R., \& Keller, K. L. (2016). Integrating marketing communications: New findings, new lessons, and new ideas. Journal of Marketing, 80(6), 122-145. [Google Scholar] [CrossRef]

Boyd, R., \& Holton, R. J. (2018). Technology, innovation, employment and power: Does robotics and Al really mean social transformation?. Journal of Sociology, 54(3), 331-345. [Google Scholar] [CrossRef]

Castelo, N. (2019). Blurring the line between human and machine: marketing Al (Doctoral dissertation, Columbia University). [Google Scholar]

Chandan. A. (2019). Factors affecting consumer buying behavior. International Journal of Advanced Research, 7(1), 563-568. [CrossRef]

Columbus, L. (2019). 10 charts that will change your perspective of Al in marketing, Retrieved from [Link]

Davenport, T. H., \& Kirby, J. (2016). Just how smart are smart machines?. MIT Sloan Management Review, 57(3), 21. [Google Scholar]

Davenport, T. H., \& Ronanki, R. (2018). Al for the real world. Harvard business review, 96(1), 108-116. [Google Scholar]

Davenport, T., Guha, A., Grewal, D., \& Bressgott, T. (2020). How Al will change the future of marketing. Journal of the Academy of Marketing Science, 48(1), 24-42. [Google Scholar] [CrossRef

Davis, B. (2018). How Al is redefining personalization \& the job of the e-mail marketer. Retrieved from [Link]

Dedehayir, O., \& Steinert, M. (2016). The hype cycle model: A review and future directions. Technological Forecasting and Social Change, 108, 28-41. [Google Scholar] [CrossRef]

Duan, Y., Edwards, J. S., \& Dwivedi, Y. K. (2019). Al for decision making in the era of Big Data-evolution, challenges and research agenda. International Journal of Information Management, 48, 63-71. [Google Scholar] [CrossRef]

Dwivedi, Y. K., Hughes, L., Ismagilova, E., Aarts, G., Coombs, C., Crick, T., . \& Williams, M. D. (2019). Al (Al): Multidisciplinary perspectives on emerging challenges, opportunities, and agenda for research, practice and policy. International Journal of Information Management, 101994. [Google Scholar] [CrossRef]

E-marketing. (2019). Trends in 2019: Al Controls Marketers and Customers. Retrieved from [Link]

Ferrell, O. C., \& Ferrell, L. (2020). Technology challenges and opportunities facing marketing education. Marketing Education Review, 30(1), 3-14. [Google Scholar] [CrossRef]

Fleming, P. (2019). Robots and organization studies: Why robots might not want to steal your job. Organization Studies, 40(1), 23-38. [Google Scholar] [CrossRef]

Goldberg, L. (2018). A brief history of Al in advertising. Retrieved from [Link]

Gordini, N., \& Veglio, V. (2017). Customers churn prediction and marketing retention strategies. An application of support vector machines based on the AUC parameter-selection technique in B2B e-commerce industry. Industrial Marketing Management, 62, 100-107. [Google Scholar] [CrossRef]

Grewal, D., Hulland, J., Kopalle, P. K., \& Karahanna, E. (2020). The future of technology and marketing: a multidisciplinary perspective. Journal of the Academy of Marketing Science, 48(1), 1-8. [Google Scholar] [CrossRef]

Hammett, E. (2018). How Lexus programmed a machine to write the world's first ai-scripted ad, Retrieved from [Link]

Harris, T. (2019). How robots work. Retrieved from [Link]

Harrison, K. (2019). 4 Ways Al Could Improve Your Marketing. Retrieved from [Link]

Herald, M. (2018). The Increasing Role of Al in Marketing Operations for SMEs. Retrieved from [Link]

Hoffman, D. L., \& Novak, T. P. (2018). Consumer and object experience in the Internet of things: An assemblage theory approach. Journal of Consumer Research, 44(6), 1178-1204. [Google Scholar] [CrossRef]

Huang, M. H., \& Rust, R. T. (2018). Al in service. Journal of Service Research, 21(2), 155-172. [Google Scholar] [CrossRef

Inversini, A., \& Masiero, L. (2014). Selling rooms online: the use of social media and online travel agents. International Journal of Contemporary Hospitality Management, 26(2), 272-292. [Google Scholar] [CrossRef]

Jabbar, A., Akhtar, P., \& Dani, S. (2020). Real-time big data processing for instantaneous marketing decisions: A problematization approach. Industrial Marketing Management, 90, 558-569. [Google Scholar] [CrossRef]

Jarrahi, M. H. (2018). Al and the future of work: Human-Al symbiosis in organizational decision making. Business Horizons, 61(4), 577-586. [Google Scholar] [CrossRef]

Järvinen, J., \& Taiminen, H. (2016). Harnessing marketing automation for B2B content marketing. Industrial Marketing

Management, 54, 164-175. [Google Scholar] [CrossRef

Jonnalagadda, V. K. (2019). The value of protecting privacy and Information Technology. Retrieved from [Link

Khodabandehlou, S., \& Rahman, M. Z. (2017). Comparison of supervised machine learning techniques for customer churn prediction based on analysis of customer behavior. Journal of Systems and Information Technology.19(1/2) , 65- 93. [Google Scholar] [CrossRef]

Kietzmann, J., Paschen, J., \& Treen, E. (2018). Al in advertising: How marketers could leverage Al along the consumer journey. Journal of Advertising Research, 58(3), 263-267. [Google Scholar] [CrossRef]

Kumar, S., \& Gupta, P. (2016). Survey of Techniques and Applications for Search Engine Optimization. Research Journal of Science and Technology, 8(2), 59-70. [Google Scholar] [CrossRef]

Lashinsky, A. (2019). Artificial intelligence: Separating the hype from the reality. Retrieved from [Link 


\section{A., Elsayed Fayed. Artificial Intelligence for Marketing Plan: the Case for E-marketing Companies}

Lessmann, S., Haupt, J., Coussement, K., \& De Bock, K. W. (2019). Targeting customers for profit: An ensemble learning framework to support marketing decision-making. Information Sciences, 4(1),115-122. [Google Scholar] [CrossRef]

Liu, X. (2020). Analyzing the impact of user-generated content on B2B Firms' stock performance: Big data analysis with machine learning methods. Industrial marketing management, 86, 30-39. [Google Scholar] [CrossRef]

Long, G. J., Lin, B. H., Cai, H. X., \& Nong, G. Z. (2020). Developing an Al (AI) Management System to Improve Product Quality and Production Efficiency in Furniture Manufacture. Procedia Computer Science, 166, 486-490. [Google Scholar] [CrossRef]

Longoni, C., Bonezzi, A., \& Morewedge, C. K. (2019). Resistance to medical artificial intelligence. Journal of Consumer Research, 46(4), 629-650. [Google Scholar] [CrossRef]

Mende, M., Scott, M. L., van Doorn, J., Grewal, D., \& Shanks, I. (2019). Service robots rising: How humanoid robots influence service experiences and elicit compensatory consumer responses. Journal of Marketing Research, 56(4), 535-556. [Google Scholar] [CrossRef]

Morgan, N. A., Whitler, K. A., Feng, H., \& Chari, S. (2019). Research in marketing strategy. Journal of the Academy of Marketing Science, 47(1), 4-29. [Google Scholar] [CrossRef]

Nasser, A. (2018). How Al Has a Strong Impact on Marketing Success. Retrieved from [Link]

Overgoor, G., Chica, M., Rand, W., \& Weishampel, A. (2019). Letting the computers take over: Using Al to solve marketing problems. California Management Review, 61(4), 156-185. [Google Scholar] [CrossRef]

Ozcelik, A. B., \& Varnali, K. (2019). Effectiveness of online behavioral targeting: A psychological perspective. Electronic Commerce Research and Applications, 33, 100819. [Google Scholar] [CrossRef]

Paschen, J., Kietzmann, J., \& Kietzmann, T. C. (2019). Al (Al) and its implications for market knowledge in B2B marketing. Journal of business \& industrial marketing, 34(7), 1410-1419. [Google Scholar] [CrossRef]

Paschen, J., Kietzmann, J., \& Kietzmann, T. C. (2019). Al (Al) and its implications for market knowledge in B2B marketing. Journal of business \& industrial marketing, 34(7), 1410-1419. [Google Scholar] [CrossRef]

Pedersen, I., Reid, S., \& Aspevig, K. (2018). Developing social robots for aging populations: A literature review of recent academic sources. Sociology Compass, 12(6), e12585. [Google Scholar] [CrossRef]

Quast, J. (2019). How Starbucks is using artificial intelligence, Retrieved from [Link

Rai, A. (2020). Explainable Al: From black box to glass box. Journal of the Academy of Marketing Science, 48(1), 137-141. [Google Scholar] [CrossRef

Rajkomar, A., Dean, J., \& Kohane, I. (2019). Machine learning in medicine. New England Journal of Medicine, 380(14), 13471358. [Google Scholar] [CrossRef]

Ransbotham, S., Khodabandeh, S., Fehling, R., LaFountain, B., \& Kiron, D. (2019). Winning With Al. MIT Sloan Management Review, 22(3), 698-706. Retrieved from [Link]

Raunaque, N., Zeeshan, M., \& Imam, M. A. (2016). Consumer Perception towards Online Marketing in India. International Journal of Advanced Engineering, management and science, 2(8), 239591. [Google Scholar

Roetzer, P. (2019). The 5P's of Marketing Artificial Intelligence. Retrieved from [Link]

Sams, A. (2018). McKinsey: Al will have the most impact in Marketing, Retrieved from [Link]

Sanchez, I. (2018). New major business trends: big data and artificial intelligence. Retrieved from [Link]

Sentance,R. (2019). 15 examples of Al in marketing. Retrieved from [Link]

Shahid, M. Z., \& Li, G. (2019). Impact of Al in Marketing: A Perspective of Marketing Professionals of Pakistan. Global Journal of Management And Business Research, 19(2) , 26-33. [Google Scholar]

Shankar, V. (2018). How Al (Al) is reshaping retailing. Journal of retailing, 94(4), 6-11.

Shen, A. (2014). Recommendations as personalized marketing: insights from customer experiences. Journal of Services Marketing, 28(5), 414-427. [Google Scholar] [CrossRef

Simon, J. P. (2019). Artificial intelligence: scope, players, markets and geography. Digital Policy, Regulation and Governance, 21(3) , 208-237. [Google Scholar] [CrossRef]

Singh, J., Brady, M., Arnold, T., \& Brown, T. (2017). The emergent field of organizational frontlines. Journal of Service Research, 20(1), 3-11. [Google Scholar] [CrossRef]

Singh, J., Flaherty, K., Sohi, R. S., Deeter-Schmelz, D., Habel, J., Le Meunier-FitzHugh, K., .. \& Onyemah, V. (2019). Sales profession and professionals in the age of digitization and Al technologies: concepts, priorities, and questions. Journal of Personal Selling \& Sales Management, 39(1), 2-22. [Google Scholar] [CrossRef]

Soni N., Sharma, E. K., Singh, N., \& Kapoor, A. (2019). Impact of Al on Businesses: from Research, Innovation, Market Deployment to Future Shifts in Business Models. Journal of Business Research, 14(3), 1124- 1139. [Google Scholar]

Syam, N., \& Sharma, A. (2018). Waiting for a sales renaissance in the fourth industrial revolution: Machine learning and Al in sales research and practice. Industrial Marketing Management, 69, 135-146. [Google Scholar] [CrossRef]

Talbot, P. (2019). The growing impact of Al on marketing strategy. Retrieved from [Link

Tjepkema, L. (2019). What Is AI Marketing \& Why Is It So Powerful. Emarsys. Noudettu, 12-9. Retrieved from [Link] Vijayaraghavan,V. (2019). How Al (Al) Could Power B2B Marketing. Retrieved from [Link]

Vincent, J., \& Gartenberg, C. (2019). Here's Amazon's new transforming Prime Air delivery drone. Retrieved from [Link

Walk-Morris, T. (2020). Walmart expands robots to 650 additional stores. Retrieved from [Link] 


\section{A., Elsayed Fayed. Artificial Intelligence for Marketing Plan: the Case for E-marketing Companies}

Wang, Y., \& Kosinski, M. (2018). Deep neural networks are more accurate than humans at detecting sexual orientation from facial images. Journal of personality and social psychology, 114(2), 246. [Google Scholar] [CrossRef]

Wang, Y., Xiong, M., \& Olya, H. (2020, January). Toward an understanding of responsible Al practices. In Proceedings of the 53rd hawaii international conference on system sciences (pp. 4962-4971). Hawaii International Conference on System Sciences (HICSS). [Google Scholar] [CrossRef]

Zhang, S., \& Cabage, N. (2017). Search engine optimization: Comparison of link building and social sharing. Journal of Computer Information Systems, 57(2), 148-159. [Google Scholar] [CrossRef]

Абір Елсаєд Фаєд, Ph.D., Університет Табук, Королівство Саудівська Аравія

Академія спеціалізованих досліджень, Єгипет

Застосування штучного інтелекту при створенні маркетингового плану: на прикладі е-маркетингових компаній

У статті узагальнено аргументи та контраргументи в рамках наукової дискусії щодо застосування штучного інтелекту (ШІ) при підготовці маркетингового плану в Інтернеті. Систематизація літературних джерел та підходів до вирішення проблеми застосування маркетингових інструментів засвідчила, що Ш дозволяє підвищити ефективність проведення аналізу конкурентоспроможності компаній, оцінювання стратегій конкурентів, планування маркетингового бюджету та моніторінгу його виконнання тощо. Виявлено проблеми ШІ, які можуть вплинути на ефективність діяльності компаній. Метою роботи є дослідження можливостей використання Ш при підготовці маркетингового плану компанії. Для досягнення поставленої мети, дослідження проведено у наступній логічній послідовності: 1) формування стратифікованої вибірки дослідження на основі статистичних даних 141 компанії в різних галузях; 2) аналіз даних за допомогою програмного забезпечення SPSS; 3) аналіз можливостей застосування Ш при підготовці маркетингового плану; 4) визначення етапів процесу підготовки маркетингового плану на основі можливостей Ш. Об'єктом дослідження є компанії Королівства Саудівської Аравії. Практичну реалізацію всіх етапів дослідження здійснено з використанням статистичних методів множинної регресії та тесту Фрідмана. Дослідження емпірично підтверджує та теоретично доводить, що Ш має суттєве значення у процесі розробки маркетингових планів завдяки можливостям аналізу зовнішнього середовища та стратегій конкурентів, а також формування маркетингових цілей компанії. При цьому Ш може застосовуватись у підготовці та оцінці бюджету та маркетингового плану, а також здійснювати подальший моніторінг ї виконання. У ході дослідження автор приходить до висновку, що Ш сприяє кращому розумінню цільових ринків та аудиторії, дозволяє підготувати відповідні стратегії. Наведено практичні рекомендації щодо особливостей застосування ШІ при підготовці маркетингового плану компанії.

Ключові слова: штучний інтелект, онлайн-маркетинг, аналіз зовнішнього середовища, маркетингові стратегії, маркетинговий план, стратегічні цілі. 